\title{
Daniel Pennac na Sala de Leitura
}

\section{Daniel Pennac in Lecture Class}

Gisele Gasparelo VOLTANI

\section{RESUMO}

Baseada nos conselhos que compõem o ensaio Como um romance, de Daniel Pennac, uma professora, que trabalha com alunos das duas primeiras séries do ensino fundamental em um projeto chamado Sala de Leitura, expõe como professores e pais podem motivar o prazer pela leitura desde a infância.

Palavras-chave: Biblioteca, Daniel Pennac, livros, sala de leitura.

\section{ABSTRACT}

Based on the advices that compose the essay Como um romance, by Daniel Pennac, a teacher, who works with children who attend the first two years of elementary school in a special project called Lecture Class, expose how teachers and relatives could motivate the pleasure for reading since infancy.

Index Terms: Library, Daniel Pennac, Books, Lecture Class. 


\section{Daniel Pennac na Sala de Leitura}

Da leitura do ensaio Como um romance, a certeza que nos resta é a de que seu autor é fiel àquilo que escreve. Daniel Pennac é hábil com as palavras como um professor-escritor deve ser. E ele nos conta uma história, como um romance. A história de como nos tornamos ou não leitores. Pennac nos faz reconhecer as armadilhas que nem nos dávamos conta que impúnhamos (como pais, professores, adultos) aos mais jovens e de como nós mesmos fomos capazes, em nossa própria gênese leitora, de sobreviver a tais armadilhas.

Sua memória remete aos primeiros contatos com o livro e a leitura. No início, quando a criança ainda não dispõe dos meios de decodificar os caracteres e fazer a leitura por si só, os adultos, geralmente os pais, fazem o papel de intermediários, lendo em voz alta o texto. Este é o primeiro e mais significativo envolvimento com o mundo da leitura, para Pennac. Mas com o passar dos anos e a escolarização, a criança é forçada à independência desta modalidade de leitor. O modo como isso acontece pode ser o entrave para a formação do seu próprio gosto pela leitura. Geralmente o que era prazer vira obrigação e o verbo ler passa a ser usado no imperativo: leia!

A escola é, por excelência, o lugar do aprendizado da leitura. Pelo menos, é isso o que os pais esperam quando a criança inicia seu processo de apreensão da língua escrita. Findo o processo de alfabetização, acredita-se que ela caminhará sozinha na sua competência leitora. Ledo engano... As armadilhas que a escolarização da leitura impõe a uma criança são imperceptíveis e parecemos estar tão certos de sua aplicabilidade, que não há contestação. É assim, e pronto. A escola parece ser o lugar da obrigação e do trabalho, o prazer e a gratuidade não são do universo escolar. E o leitor que esperamos não pode vir sem que a leitura passe pelo prazer e gratuidade, como era nos tempos de criança. “O verbo ler não suporta o 
imperativo” (PENNAC, 1998, p.13).

Mas, se a leitura como é tratada na escola parece fadada ao fracasso, o que fazer? Em contrapartida, Pennac nos oferece alguns caminhos possíveis para a mudança. A gratuidade em relação à leitura precisa ser retomada em sala de aula. Segundo o autor: "Uma só condição para se reconciliar com a leitura: não pedir nada em troca” (PENNAC, 1998, p.121).

Há de se considerar a possibilidade de o professor, ao invés de cobrar o entendimento do texto, compartilhar com seus alunos a experiência da leitura em voz alta. O professor que lê em voz alta o faz para leitores que não sabem ler, não por não serem alfabetizados, mas porque a vivência de leitura não se restringe à capacidade de decifrar o código escrito. As modulações de intenção, de situação de sua voz produzem o sentido que ainda não é tão fácil de ser percebido pelos jovens leitores. Por fim, Pennac elenca dez direitos do leitor, dentre os quais estão o direito de não ler; o direito de não terminar um livro, o direito de ler qualquer coisa e o direito de calar sobre sua leitura. Os dez direitos do leitor que são elencados por ele, nada mais são que o respeito ao espaço necessário para que o sujeito se faça como leitor.

A Sala de Leitura nas escolas municipais de São Paulo, como outros ambientes diferenciados na escola, tem por meta auxiliar no processo educativo como um todo. Os chamados Professores Orientadores de Sala de Leitura (POSL) são professores da escola eleitos pelo Conselho de Escola para desempenhar esta função e dar uma aula semanal para cada turma no espaço da biblioteca. De modo geral, a Sala de Leitura tem por objetivo o estímulo à leitura de diversos gêneros em diferentes suportes, a interpretação e a produções criativas a partir da leitura. Como chegar a isso? Daniel Pennac se orgulharia de ver que o trabalho aí realizado encontra muitas semelhanças com sua proposta de amor à leitura.

Comecemos pela leitura em voz alta. Como não poderia deixar de 
ser, a leitura de histórias é uma parte fundamental do trabalho. Os personagens ganham vida nas modulações, nas pausas e aceleramentos do ritmo de voz. Algumas atividades e jogos antes da história, chamadas de pré-leitura, preparam o educando para a compreensão do texto. Tais atividades utilizam habilidades de leitura e também mexem com sua criatividade. São diversos jogos que elaborei, como montar palavras ou inventar um texto a partir de palavras que aparecerão na história do dia. O trabalho em grupo é fundamental. A própria configuração da Sala de Leitura, com mesas redondas, possibilita a convivência e a necessidade do aprendizado desta convivência em grupo.

Após a leitura semanal em voz alta, o que é pedido em troca? Uma relação das personagens principais? A compreensão do texto? Não, nada disso faz parte da vivência na Sala de Leitura. Finda a leitura do professor, o livro é fechado e partimos para a próxima parte da aula: o empréstimo de livros.

A Sala de Leitura da EMEF Paulo Setúbal tem suas prateleiras divididas e identificadas com cores que separam a literatura infantil, da juvenil e adulta e da pesquisa, além de gêneros (romance, conto, crônica, poesia, ficção) e assuntos que mais interessam ao grupo de nossa escola (folclore, livros-jogo, livros só de imagem). Assim cada faixa etária já sabe em que prateleira encontrará um livro que mais se aproxime de seus gostos. Nos encontros semanais, cada aluno pode levar (ou não) um livro de sua livre escolha, que será devolvido na semana seguinte quando, então, ele poderá levar outro. Respeitam-se aqui dois direitos: o de não ler e o de ler qualquer coisa.

Sempre no começo da aula, antes da atividade por mim preparada, os alunos são chamados a devolver os livros e estimulados a fazer uma pequena "propaganda" daquilo que leram (ou ouviram da leitura dos pais, irmãos mais velhos, avós...). Eles contam um pedaço da história, ou mostram a ilustração correspondente à parte preferida. Desse modo, há a 
troca de informações sobre os livros que, muitas vezes, despertam o interesse pelos mesmos e estimulam os pedidos de empréstimo das referidas obras. Mas esta exposição é voluntária. Mais dois direitos respeitados: o de ler em voz alta e o de calar.

Na verdade, o empréstimo semanal de livros na Sala de Leitura busca o respeito a todos os direitos do leitor enumerados por Daniel Pennac. O aluno pode escolher se leva ou não um livro para casa. Dado que não será pedido nada em contrapartida ao empréstimo, ele pode fazer o uso que quiser desse livro, pois que o mesmo será seu durante uma semana. Ele pode lê-lo ou não, por inteiro ou algumas partes, começar e não acabar, reencontrar-se na semana seguinte com um livro já lido (por ele ou pela professora).

O que posso afirmar, correspondendo às expectativas do autor de Como um romance, é que um número significativo de crianças empresta mais e mais livros durante o percurso dos quatro anos em que permanecem no Ciclo I do Ensino Fundamental. E é reconfortante reconhecer que faço parte desta aquisição, desta primeira vontade de ouvir mais e da posterior vontade de ler mais, sem que para isso tenha sido usado nenhum só dia o insuportável imperativo do verbo ler.

\section{Referências bibliográficas}

PENNAC, Daniel (1998). Como um Romance. Tradução de Leny Werneck. 4ªed. Rio de Janeiro: Rocco. 


\section{Autora:}

\section{Gisele Gasparelo Voltani}

Titulação: Bacharelado em História (FFLCH-USP / 2002); Licenciatura em História (FE-USP / 2003); Pedagogia (FE-USP / cursando o segundo ano). Instituição a que pertence(m) e cargo que ocupa(m); EMEF "Paulo Setúbal" Professora Titular de Ensino Fundamental I (desde 1999); Professora Orientadora de Sala de Leitura (desde 2002) - Local em que ocorreu a prática docente; alunos envolvidos; responsável pela prática e facilitadores para a sua realização. - EMEF Paulo Setúbal - Cidade de São Paulo. Alunos do Ensino Fundamental - Ciclo I. POSL.

Endereço profissional: Escola Municipal de Ensino Fundamental "Paulo Setúbal” R Francisco de Caldas, 50 - Jd Ana Lúcia. São Paulo - SP. 56616313. Endereço residencial:_R. Paulo Araújo Novaes, 339 - Pq América CEP 04822-010 São Paulo - SP. 5661-4196 gizbr@yahoo.com.br

\section{Como citar este depoimento:}

VOLTANI, Gisele Gasparelo. Daniel Pennac na Sala de Leitura. Revista ACOALFAplp: Acolhendo a Alfabetização nos Países de Língua portuguesa, São Paulo, ano 2, n. 4, 2008. Disponível em: $<$ http://www.mocambras.org > e ou <http://www.acoalfaplp.org >. Publicado em: março 2008. 